\title{
COMPARATIVE ANALYSIS ON PROVIDING THE SERVICE IN IC TRAINS BETWEEN REPUBLIC OF SLOVAKIA AND REPUBLIC OF CROATIA
}

\author{
Borna Abramović ${ }^{1}$, Eva Nedeliakova ${ }^{2}$, Dinko Lukinić ${ }^{3}$ \\ ${ }^{1,3}$ University of Zagreb, Faculty of Transport and Traffic Sciences, Zagreb, Croatia \\ ${ }^{2}$ University of Žilina, Faculty of Operation and Economics of Transport and Communications, Žilina, Slovakia
}

Received 19 February 2015; accepted 9 July 2015

\begin{abstract}
In today's liberalized market of passenger railway services are in use trains ranks. Train rank means a level of service that has applied on train. The highest ranks trains are Eurocity and Intercity. Eurocity trains generally connect major cities between at least two countries, while the Intercity trains typically connect important cities in a state. The survey is the standard way to examine passenger's satisfaction. Therefore, this survey has been conducted in the Slovak and Croatian Intercity trains. Analysis of survey results show some strong and some weak points of each operator and the habits and opinions of the passengers. Based on the results of the survey, improvements are necessary in the punctuality, comfort and in providing Wi-Fi services. It is necessary to establish methods for developing services that will bring higher satisfaction of passengers as the final aim.
\end{abstract}

Keywords: intercity trains, survey, passengers transport services, comfort, punctuality, frequency of use, alternative, staff, Wi-Fi service.

\section{Introduction}

The first public passenger transport by railway has established on the line Stockton - Darlington in 1825 in the UK. Today, passenger railway has an important place in the offer of public transport, both in urban, suburban, domestic and international traffic. Particularly in the last few years there are very interesting research of the service quality in public transport, as well as in railway passengers transport.

A comprehensive approach to conducting surveys for the purposes of transport planning is made in the book Survey Methods for Transport Planning by Richardson et al. (1995). Authors Dell'Olio et al. (2011) made a research how to use surveys to determine the desired level of service quality for users of public transport. Then authors Chang and Yeh (2002) made a very interesting research in the field of air transport about service quality on domestic flights using surveys. Also Dolinayova (2011) investigates factors and determinants of modal split in passenger transport. Then in the field of railway passenger traffic De Oña et al. (2014) using surveys did a research in the area of northern Italy, and with the help of a decision tree

\footnotetext{
${ }^{1}$ Corresponding author: babramovic@fpz.hr
} 
approach conducted the analysis of the data collected. In addition, authors Nedeliaková et al. (2014) made proposal of methodology for identification level of service quality in railway transport and Abramović (2015) made a research of the mobility of railway passenger transport in small urban areas.

By classification of passenger trains in the categories of domestic and international traffic, Intercity trains constitute the highest category of trains in domestic traffic. The classification is made according to the level of transport services, travel time and the price of transportation. Intercity trains are intended to connect the region centres of the state and enable passenger the most comfortable transport: air-conditioned, the option of using electricity, Wi-Fi service and consumption of hot and cold food and drinks in the restaurant car. The task of analysis of transport services in Intercity trains was to find out the habits of passengers and their opinion about services offered by the railway operator in two different states of the European Union, Republic of Slovakia and Republic of Croatia. Following analysis points the necessary changes of individual characteristics and the development of transport services focused on the user's needs.

\section{Passengers Satisfaction Research Methodology}

The survey research has to induce, collect and then analyse the statements of passengers on the given questions. Using the survey, it is possible to find out opinions and thoughts about their satisfaction about travelling by train in the Republic of Slovakia and the Republic of Croatia. Such kind of survey is limited, because its results depend on the honesty of the passengers and their ability to respond to the questions. However, well constructed and tested survey, adequate research problem, representative sample of respondents and appropriate data analysis may provide useful information about the satisfaction of passengers. The statements are evoked by thought-out questions which should be simple, clear, unambiguous and non-leading. Questions can be printed in the form of questionnaire or verbally through interview. The most common way to research satisfaction of passengers is the form of survey conducted in the train in order to arouse the senses of the current train ride. The sample must be representative for the population being studied. Finally, registered replies are being processed by different statistical analysis.

The content of the Croatian and Slovak survey was not formed in the completely same way. The differences are mainly related to the issue of Wi-Fi service, its accessibility and billing, and questions about the level of income and the purpose of travel.

The reason for such differences is the absence of $\mathrm{Wi}-\mathrm{Fi}$ service in Croatian trains.

Republic of Croatia survey version contains 15 questions, 5 of general nature, and 10 thematic questions. Slovak version of the survey consists of 19 questions, 5 questions of general nature and 14 thematic. The general part of the survey analyses sex, age, educational level and frequency of using railway transport.

The content of thematic questions within the survey includes evaluation of employees work and expressing opinions about specific characteristics of the railway operator. 
The survey on the level of satisfaction of transport service in the Republic of Slovakia has been conducted in the three day period in Intercity trains on the route Bratislava Žilina. Survey in Republic of Slovakia has been supported by Železnična spoločnost Slovensko (Passengers railway undertaking of Slovakia).

The selected route for the survey in Croatia was relation Zagreb - Slavonski Brod. Contrary to the Slovak survey, Croatian survey was not conducted in the Intercity trains, but in Eurocity and speed passenger trains. In timetable 2013/2014 the traffic of Intercity trains on the route Zagreb - Slavonski Brod has been cancelled. The implementation of the survey in the Republic of Croatia has been supported by HŽ Putnički prijevoz (Passengers railway undertaking of Croatia). Geographical location of railway line in the Republic of Croatia (left) and the Republic of Slovakia (right) is shown in Fig. 1.

It was collected 292 survey sheets in the Republic of Slovakia, and 341 survey sheet in the Republic of Croatia.
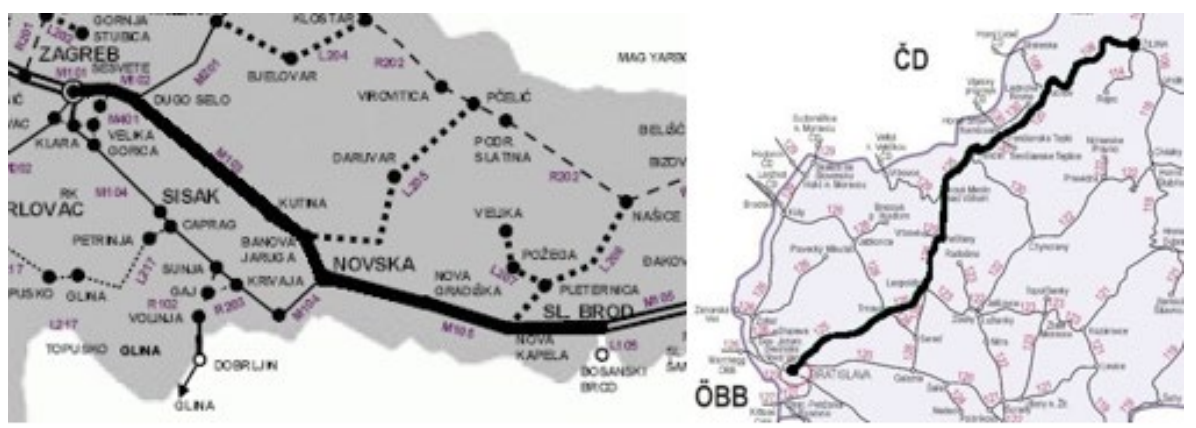

Fig. 1.

Geographical Location Relations in the Republic of Croatia and the Republic of Slovakia Source: Lukinić (2014)

\section{Survey Results Analyses}

Analysis of survey results consists of two parts, the analysis of general questions and analysis of thematical questions. The general questions include a standard basic statistical issue, while thematic questions relate to specific research of train in the Republic of Slovakia and the Republic of Croatia.

\subsection{General Questions Analyses}

A general questions analysis is based on the results of the part of the survey that is same in both countries. At the question about sex, the passenger could choose between male and female. In both countries number of female passengers was higher than number of male passengers: in Slovak survey 58\%:42\% and in Croatian survey $52 \%: 48 \%$.

Filling out basic information, passengers could choose among 7 levels of age. Each level of age covered 10 years period, only two levels had different grades. One of them is juveniles which include period up to 18 years of age and the second are passengers older than 64 years. Number of juvenile passengers 
is higher in Croatian trains and makes $6 \%$ of passengers, while in the Slovak trains makes only $1 \%$ of passengers. The percentage of passengers is equal in levels $18-24(24 \%)$, 25-34 (21\%), 45-54 (14\%) and over 64 years (7\% of passengers).

On the other side, levels of passengers aged 35-44 and 55-64 years differ in two surveys. At the level of the age 35-44 years 6\% more passengers travels in Slovak than in Croatian where the same level was chosen by $15 \%$ of passengers. Level of age 55-64 years differs $4 \%$. The number of such passengers is higher in Slovak trains and is $15 \%$ of total surveyed Slovak passengers. The distribution of respondents according to the age criteria is shown in Fig. 2.

It is difficult to make comparison of education level within the research because of many differences between Croatian and
Slovak education system. However, primary education is comparable, but there are big differences between Slovak and Croatian passengers. Among the surveyed passengers in Slovakian Intercity trains only $1 \%$ has primary education while in Croatia percentage of such passengers is $10 \%$.

There are much more passenger with secondary education level so the percentage value is $43 \%$ in the Slovak trains and $49 \%$ in Croatian trains. There are significant differences in higher education between Slovakia and Croatia. In Slovakia, in higher education there are three degrees levels, while in Croatia there are four degrees levels. Therefore, in Fig. 3 are separated representation for Slovakia and Croatia. In Slovakia, 56\% completed higher education, while in Croatia $40 \%$ completed higher education. Percentage values of all other levels of education are evident in Fig. 3.

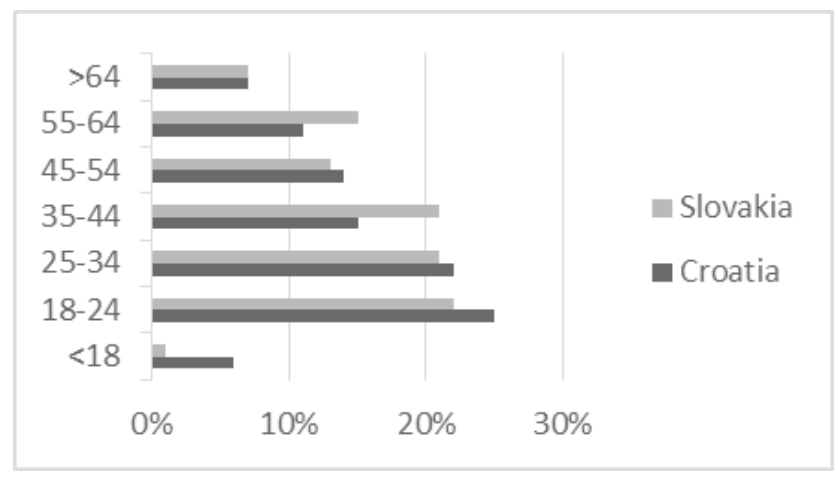

Fig. 2.

Distribution of Passengers According to Criteria of Age

Source: Lukinić (2014) 


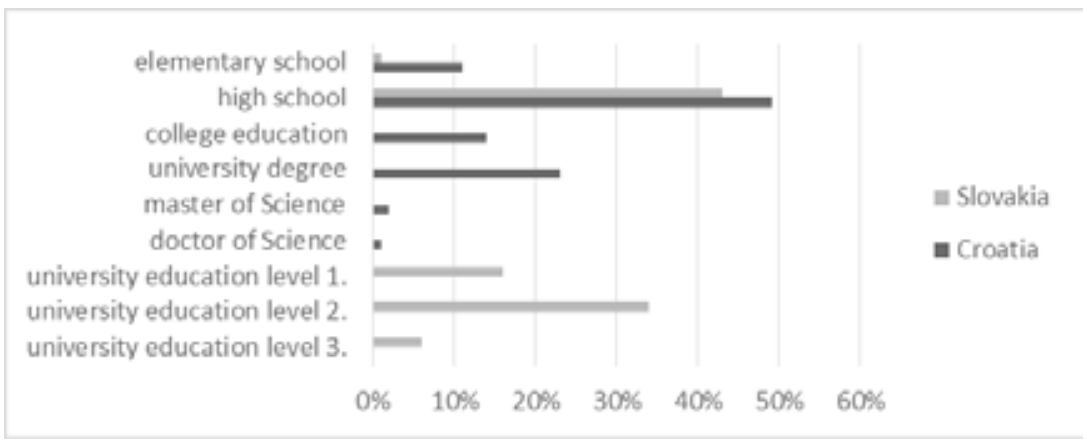

Fig. 3.

Distribution of Passengers According to the Criteria Level of Education

Source: Lukinić (2014)

\subsection{Analysis of Thematic Issues}

The analysis of thematic questions provides facts about user's opinion on the individual characteristics of train transport services. Most of the questions had answers were used the answers in the form of numerical marks from 1 to 5, where 1 meant the worst rating grade and 5 the best grade.

Further analysis deals with the following characteristics: travel comfort, punctuality, extra services and railway staff evaluation.

\subsubsection{Travel Comfort}

Due to the travel comfort railway is very well accepted as a mode of transport.

Under the comfort is considered: enough space for sitting (sleeping in a sleeping car), the possibility of movement while driving, available toilet and air-conditioned interior.

According to the analysis of both surveys, Slovak travellers are much more satisfied with the comfort of traveling by trains than Croatian passengers. Grade 1 was marked by the $3 \%$ of passengers in both surveys and this is the only grade with the same number of responses in both surveys. Bad mark was given by $13 \%$ of Croatian respondents and $7 \%$ of Slovak respondents. With average grade of comfort, grade 3 , Croatian trains were rated by $44 \%$ of respondents, and the Slovak trains by $33 \%$ of respondents. The difference of $9 \%$ in favour of the Slovak operator appears in marks very good and excellent. As a very good, comfort in Slovak trains was rated by $41 \%$ of respondents and in Croatian trains by $32 \%$ of them. That comfort in trains is excellent; consider $17 \%$ of Slovak passengers. Summing grades very good and excellent in the category of comfort it can be noticed a big difference between Slovak and Croatian operators. The sum of these two grades expressed as a percentage is $40 \%$ in Croatian survey and $58 \%$ in Slovak survey. The reason of such a difference probably lies in a better adjustment of Slovak operator to the needs of its users. It should be noted that Slovak Intercity trains contain restaurant cars, special section for mothers with small children, Wi-Fi service and access for passengers with reduced mobility. Comparative overview of grade according to the criteria traveling comfort is shown in Fig. 4. 


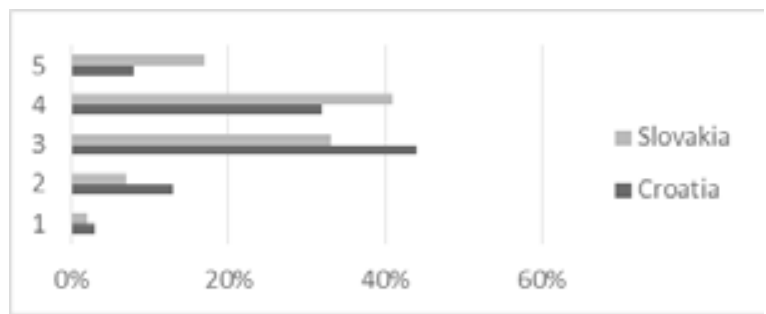

Fig. 4.

Distribution of Grade According to the Criteria Traveling Comfort

Source: Lukinić (2014)

\subsubsection{The Frequency of Travel of Passengers}

The mobility of passengers is marked with frequency of passengers traveling in the period of a week. If the passenger does not travel so often by Intercity trains, it implies that he travels only a few times a year. The number of passengers who travel several times a year in both countries is very high. In Croatia every second passenger in the survey travels several times a year, and in Slovakia the same number of travels takes every third traveller. The percentage of passengers who travel once a week in Slovak trains is $50 \%$ and in Croatia $13 \%$. In Slovakia $11 \%$ of passengers make two round trips per week while in Croatia same number of trips per week makes $17 \%$ of passengers. It is interesting that the same difference of
$6 \%$ appears in the number of travels three times a week, which means $7 \%$ of Croatian passengers versus $1 \%$ of Slovak passengers.

In the surveys conducted in Slovak trains, there is no recorded answer with the number of travels four times a week. In Croatia, number of such answers is $3 \%$. The difference of even $9 \%$ is evident in the number of travels five times a week. The survey shows that $10 \%$ of passengers in Croatia travel five times a week, while in Slovakia only $1 \%$. Only one traveller in each country travels six times a week. Number of everyday passenger's in Croatia is 7 which is $2 \%$ of the total surveyed, while in Slovakia daily trip take only 2 persons which means $1 \%$. This confirms a better mobility in Slovakia, probably thanks to tactfully set timetable of Intercity trains. The frequency of passengers travel is shown in Fig. 5.

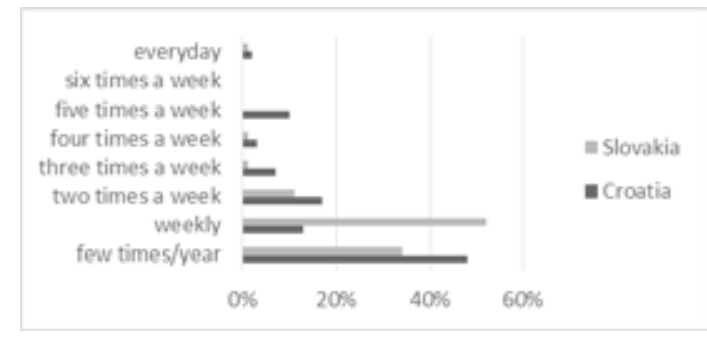

Fig. 5.

Level of Mobility in Republic of Slovakia and Republic of Croatia

Source: Lukinić (2014) 


\subsubsection{The Punctuality of Travel}

The most recognizable characteristics of railway are the punctuality of the travel. It means timely arrival at the destination and proper implementation of train timetable.

Punctuality of Intercity trains in surveys was rated average, with grade good. In the Croatian survey percent is $29 \%$ and in the Slovak survey $27 \%$ of passengers. It is interesting those $58 \%$ passengers in Slovak survey thinks that the punctuality of trains is very good or excellent, and $51 \%$ of passengers in Croatian survey considers very bad and bad. If we compare the use of mark very well in Croatian and Slovak survey, the difference of $23 \%$ is on the side on the Slovak survey, and if we compare the rating very bad, the dominance of $21 \%$ is on the side of Croatian survey. Criteria punctuality of train is shown in Fig. 6.

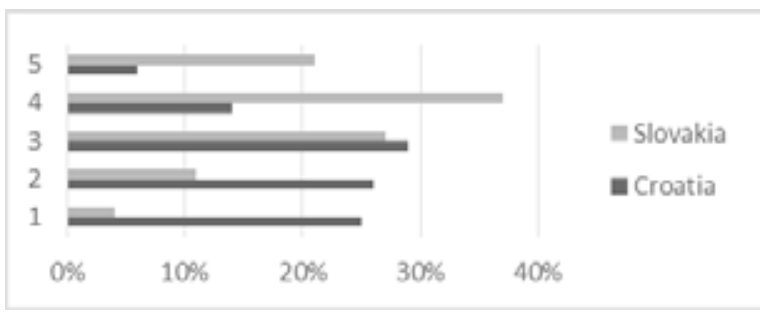

Fig. 6.

Distribution of Grade According to the Criteria Punctuality of Train

Source: Lukinić (2014)

\subsubsection{Alternative Travel}

The question about alternative travel relates to the reason why travellers use railway. Accordingly, the alternative is the number of people using the railways because of the lack of alternative modes of transportation on the surveyed route.

The analysis of Croatian survey shows that $24 \%$ of passengers are forced to use the railway because so there is no other option, while in the Slovak survey same answer makes $8 \%$ of the total surveyed. The most common reasons of absence of the alternative modes of travel are not possession of a driver's license or car and inadequate timetable of bus lines. In Croatian survey such responses make almost a quarter of all responses. Such survey results are an important reminder to Croatian railway operator to the future development so passengers use it because of quality of it is services, and not as only option. Share of alternative travel is shown in Fig. 7.

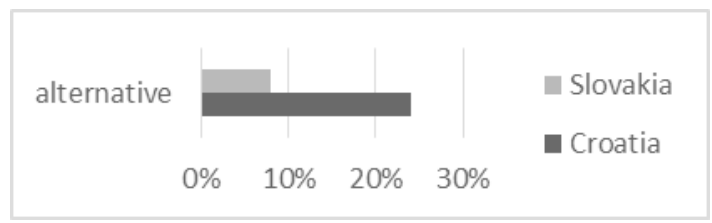

Fig. 7.

Level Absence of Alternative Modes of Transportation

Source: Lukinić (2014) 


\subsubsection{Train Staff}

As the work of terminal staff, the work of train staff is highly rated. The evaluation of train staff in the survey includes evaluation of performance, accessibility and kindness. When we take into account all the marks, the better ones are given to the staff in Croatian trains. Scores very good and excellent are chosen by $75 \%$ of Croatian passengers, and $64 \%$ of Slovak passengers. Difference of $4 \%$ on the Slovak side relates to the scores very bad, bad and good (grades 1, 2 and 3) so Slovak passengers declared like this: $5 \%$ of subjects for evaluation very bad, $7 \%$ for the evaluation bad and $24 \%$ for evaluation good. The most common rating for the train staff work is very good, which is chosen by $82 \%$ of respondents, $43 \%$ in the Croatian survey, and $39 \%$ in the Slovakian survey. Comparative overview of grade according to the criteria work of staff in train is shown in Fig. 8.

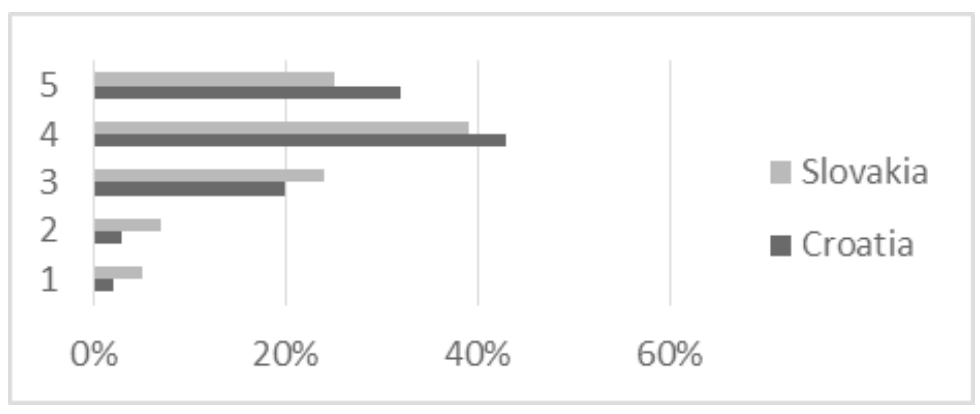

Fig. 8.

Distribution of Grade According to the Criteria Work of Staff in Train Source: Lukinić (2014)

\subsubsection{Wi-Fi Service}

The need for the introduction or improvement of wireless internet in trains is offered in terms within the questions about Wi-Fi. The results show a great interest of passengers for the introduction of wireless internet in trains in the Republic of Croatia. At the moment, there are no such systems in Croatian trains, but $90 \%$ of the passengers think it would be necessary to introduce it. Slovak trains pass such systems, but $96 \%$ of Slovak passengers consider that would be necessary to implement it in all trains.

In modern era of communications, it is difficult to imagine that a modern railway operator does not offer connection to the Internet. The operator who wants to improve it is transport service, should be interested in implementation of internet services. Distribution for need to introduce Wi-Fi service in trains is shown in Fig. 9. 


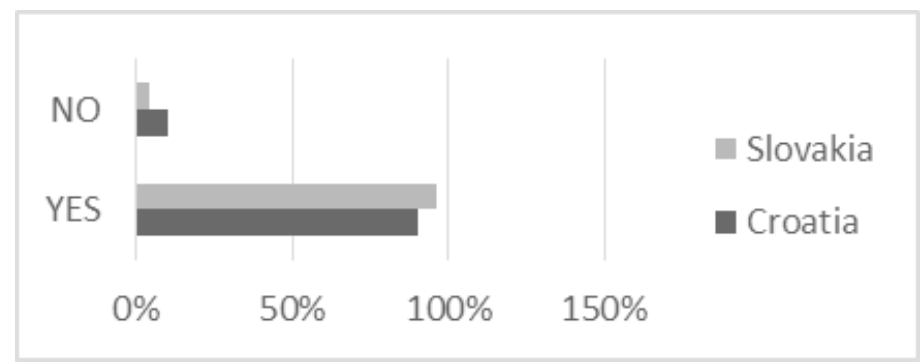

Fig. 9.

Needs to Introduce Wi-Fi Service in Trains

Source: Lukinić (2014)

\section{Conclusion}

For the future development of each individual transport sector, it is necessary to determine appropriate policy that will put directions of development for several years, even decades. The European Union regularly publishes European transport policy for a period of 10 years. It is difficult to achieve such aims using outdated structural documents, or not abiding by the rules. Such problems are present in the Republic of Croatia, especially in the railway transport sector. In order to raise the level of train transport services, or generally the service that railway operator provides, it is necessary to have a feedback with users.

Therefore, there is constantly need to conduct surveys in trains. The surveys are very powerful tool to gathering the passenger's picture of service. In today's time, it is easy to conduct survey because of use of simply software solution and modern equipment, such as smart phones or tablet. Railway operator that want satisfied passengers regularly conduct the survey and then adjust their service to passenger. In this way they are keeping exist passengers and can bring to them new passengers.
A good example of such relationship between operator and users can be found in Železnična spoločnost Slovensko. They do research and surveys several times a year and considers research results. By this approach, the operator constantly increases capacities and develops the transport service according the customers desires. Comparing these two railway operators it is obvious that $\mathrm{HZZ}$ Putnički prijevoz has to invest a lot of effort, hard work, will and desire to reach the level of Železnična spoločnost Slovensko, and increase their competitiveness in the liberalized railway services mark of European Union.

\section{References}

Abramović, B. 2015. Analysis of the mobility of railway passenger transport in small urban areas, Urban transport XXI, Southampton, WIT Press. DOI: http://dx.doi. org/10.2495/UT150541.

Chang, Y-H.; Hsing Yeh, C-H. 2002. A survey analysis of service quality for domestic airlines, European Journal of Operational Research. DOI: http://dx.doi.org/10.1016/ S0377-2217(01)00148-5, 139(1): 166-177.

De Oña, R.; Eboli, L.; Mazzulla, G. 2014. Key factors affecting rail service quality in the Northern Italy: a decision tree approach, Transport. DOI: http://dx.doi. org/10.3846/16484142.2014.898216, 29(1): 75-83. 
Dell'Olio, L.; Ibeas, A.; Ceca, P. 2011. The quality of service desired by public transport users, Transport Policy. DOI: http://dx.doi.org/10.1016/j.tranpol.2010.08.005, 18(1): 217-227.

Dolinayova, A. 2011. Factors and determinants of modal split in passenger transport, Horizons of Railway Transport, Žilina. ISSN 1338-287X, 2(1): 33-39.

Lukinić, D. 2014. Comparative analysis on providing the service in IC trains between Republic of Slovakia and Republic of Croatia (in Croatian), Faculty of Transport and Traffic Sciences, Zagreb.
Nedeliaková, E.; Sekulová, J.; Nedeliak, I.; L'och, M. 2014. Methodics of identification level of service quality in railway transport, Procedia - Social and Behavioral Sciences. DOI: http://dx.doi.org/10.1016/j. sbspro.2013.12.876, 110: 320-329.

Richardson, A.J.; Ampt, E.S.; Meyburg, A.H. 1995. Survey methodsfor transport planning, Parkville, Eucalyptus Press and University of Melbourne. 475 p. 